\title{
Study on the Applicability of Landsat-8 Images as a Tool for Monitoring the Trophic State of Lake Guiers (Senegal)
}

\author{
Charles Diédhiou1, Seybatou Diop1 ${ }^{\text {[D }}$, Gayane Faye1, Tijani Moshod², Souléye Wade1 \\ ${ }^{1}$ Institute of Earth Sciences, Faculty of Sciences and Techniques, Cheikh Anta Diop University, Dakar, Senegal \\ ${ }^{2}$ Department of Geology, University of Ibadan, Ibadan, Nigeria \\ Email: charlesdiedhiou79@gmail.com, seybdiop@yahoo.fr, gayane.faye@gmail.com,tmoshood@yahoo.com, wadesouleye@yahoo.fr
}

How to cite this paper: Diédhiou, C., Diop, S., Faye, G., Moshod, T. and Wade, S. (2019) Study on the Applicability of Landsat-8 Images as a Tool for Monitoring the Trophic State of Lake Guiers (Senegal). Journal of Water Resource and Protection, 11, 434-447.

https://doi.org/10.4236/jwarp.2019.114026

Received: February 11, 2019

Accepted: April 27, 2019

Published: April 30, 2019

Copyright $\odot 2019$ by author(s) and Scientific Research Publishing Inc. This work is licensed under the Creative Commons Attribution International License (CC BY 4.0).

http://creativecommons.org/licenses/by/4.0/

(c) $\underset{\mathrm{EY}}{\mathrm{C}}$ Open Access

\begin{abstract}
In this study, an algorithm to transform LANDSAT 8 images of Lake Guiers into chlorophyll-a concentration maps was developed. The objective was to see the feasibility of this method as a mapping tool for monitoring the trophic state of the Lake. The available data are 15 in-situ measurements of the CHL-a content of Lake Guiers' water using a Micro FLU device and images of the lake acquired in 2013 and 2016 by the LANSAT 8 OLI sensor. A series of correlation tests (simple linear functions, multi-variables, or containing twoorder terms) were performed between the spectral sensor signal of June 19, 2016 LANSAT 8 image ("corrected" and converted into reflectance) and the CHL-a content of Lake waters measured on the same day of the satellite record. This was, to find the best regression equation that can be inferred to develop an algorithm to transform LANDSAT 8 image into CHL-a concentration maps. The best equation obtained by correlating the ground truths and the reflectance ratios of the visible and near infrared bands (B2, B3, B4 and B5), is as follows:
\end{abstract}

$$
Y=3.4 *\left(\frac{\mathrm{B} 3-\mathrm{B} 2)}{\mathrm{B} 4}+\frac{\mathrm{B} 5}{\mathrm{~B} 4}\right)+2.37 .
$$

where B2 = Blue band, B3 = Green band, B4 = Red band, B5 = NIR band. The obtained $R^{2}$ is 0.703 (e.g., a correlation coefficient $r=\sqrt{\left(R^{2}\right)}$ of 0.84 ), revealed that the measured concentrations are well reproduced by the regression model. Applying this model to the 2013 and 2016 image data revealed the monthly variations of the lake CHL-a contents and their seasonal evolution and interannual variations. The obtained results are quite consistent with those from similar studies and provide valuable information regarding Lake Guiers' vulnerability to algal development. The calculation and analysis of the 
variability of the CHL-a contents over the study period made it possible to evaluate the trophic state of the Lake, which shows a general tendency for eutrophication process, leading to a progressive degradation of the quality of the water resource.

\section{Keywords}

Lake Guiers, LANDSAT 8, Chlorophyll a, Trophic State

\section{Introduction}

The collective effects of climate change and environmental impacts associated with the development activities in the Lake Guiers' basin (i.e. intensive agricultural and industrial activities, changes in land-use practices, waste-disposal practices of domestic and industrial waters) have impacted adversely on the quality of this important resource for drink water supply in Senegal. The lake supplies nearly $60 \%$ of the country's water demand; hence its degradation would imply a serious water problem.

The problems that have emerged are essentially a continuous quality deterioration of the environment of the lake, with the risk to failing to meet its beneficial uses ([1] [2]). To deal with this situation, the state authorities proposed the establishment of Lake Guiers Office (Office du Lac de Guiers) in 2009; a state agency whose mission is the protection and management of this natural resource.

Under these conditions, monitoring of the lake water quality has become a major challenge. However, because of the size of the lake, the conventional approach of in situ measurements, with sampling and subsequent laboratory analysis is not ideal due to tedious and expensive nature of such exercise. Nowadays, the common practice is to use remote sensing techniques, which can provide a rapid complementary mean to collect large-scale information on lake's water quality. The potential applications of this technique have been greatly enhanced in recent years, due to the development of a new generation of satellites, with higher spatial, spectral and temporal resolution [3] [4] [5]). Remote sensing has the advantage of providing regular data coverage over a large scale area, and many studies have demonstrated its ability to monitor surface water quality parameters like chlorophyll-a or turbidity, suspended sediment loads and coloured dissolved organic matter ([6]-[11]).

The purpose of this study is to demonstrate the usability of LANDSAT-8 images for monitoring the CHL-a content of Lake Guiers waters. There is a relation between the optical signal measured by satellite sensors and the chlorophyll-a (CHL-a) content of a target surface water. LANDSAT-8 images have spectral bands that are very sensitive to the variations of the concentration of chlorophyll-a pigment, and thus could be used to observe this water quality parameter. It is important to note that CHL-a is a pigment that is present in all organisms 
that photosynthesize, and especially by algae. Hence, it is an indicator of the abundance or quantity of phytoplankton present in nutrient-rich lake waters (e.g., nitrogen and phosphorus).

\section{Presentation of the Study Area}

Lake Guiers is an important freshwater resource for Senegal. It is located to the North of the country, between Latitude: $16^{\circ} 00^{\prime}-16^{\circ} 30^{\prime}$ North, and Longitude: $15^{\circ} 40^{\prime}-16^{\circ} 00^{\prime}$ West (see Figure 1). It is a small lake, with a surface area of about $350 \mathrm{~km}^{2}(50 \mathrm{~km} \times 7 \mathrm{~km})$, and a maximum depth of $4 \mathrm{~m}$, corresponding to a total volume of water of nearly 600 million $\mathrm{m}^{3}$ ([12]).

It is fed by the Senegal River through the Taoué Canal, which artificially ensure that the water surface is maintained at a constant level of about $+2 \mathrm{~m}$ above mean sea level ([13]). The lake physiography can be subdivided into three main regions ([14]):

1) A northern, upstream, turbid waters zone (where waters of the Senegal river enters the lake) located near large irrigated areas;

2) A central zone, the deepest part of the lake, where water resource development plants for the drinking water-supply have been installed; and

3) A southern, downstream, shallow water zone, with numerous emergent sand bars and a dense aquatic vegetation.

Downstream, the lake discharges its waters through the Keur Momar Sarr dam that regulate its flow discharge (see Figure 1). According to ([15]), the northern and central parts of the lake include nearly $90 \%$ of the reserves.

The climate of the region is Sahelian type (arid), marked by the concurrence

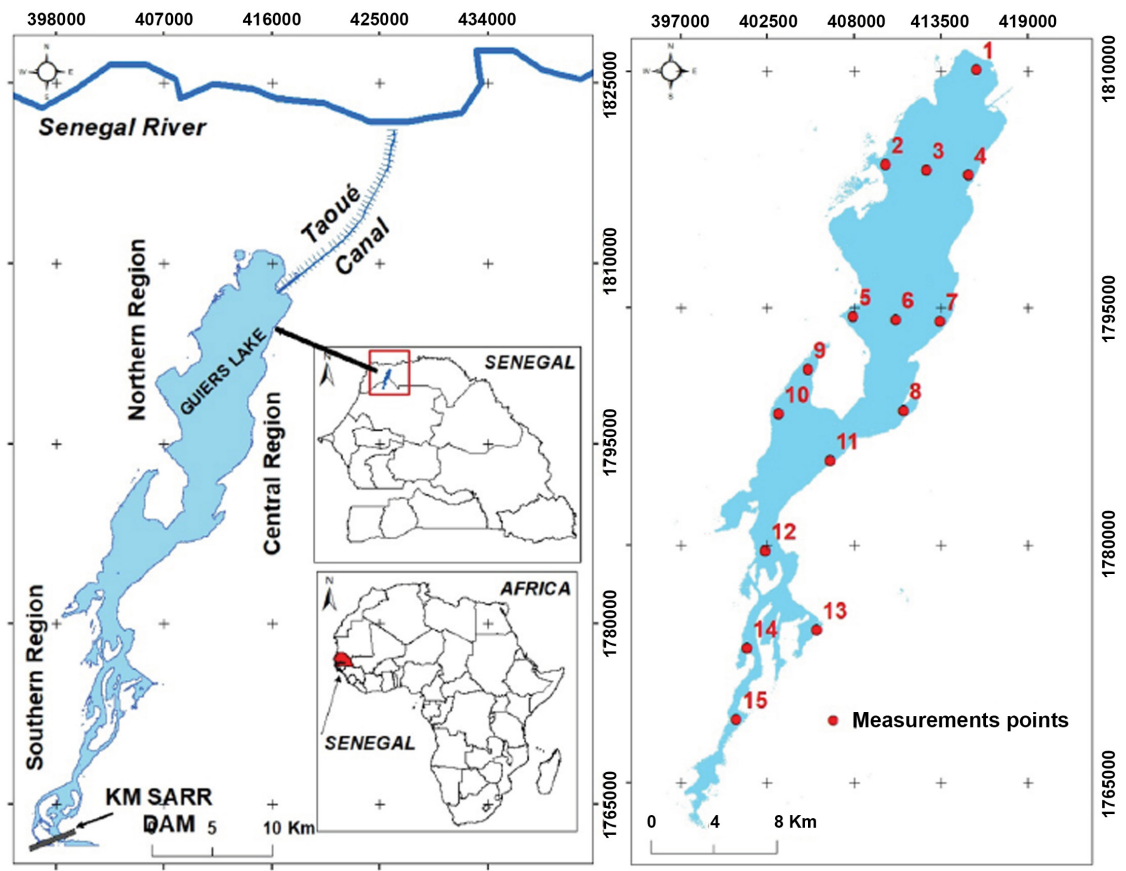

Figure 1. Location map of study area in Senegal and of the CHL-a measurement points in the lake. 
of high temperatures, low precipitations and high evaporation rates. Temperatures reach $17^{\circ} \mathrm{C}-30^{\circ} \mathrm{C}$ (mean of $27^{\circ} \mathrm{C}$ ). There are two seasons: a dry season that lasts from October to June, and a rainy season, from July to September. Rainfalls are marked by a strong seasonal and interannual variability. The annual rainfalls range between 100 to $400 \mathrm{~mm}$. The zone experiences two wind types that control the seasons: the Saharan trade wind (so-called Harmatan) that blows in the general north-easterly direction during the dry season; and the south-westerly monsoon currents that carry humid maritime air masses and brings in the rainy weather conditions. The area is covered by a shrub steppe vegetation and bare soils. The subsurface geology includes Quaternary sand dunes underlain by Tertiary marl-limestones.

\section{Material and Methods}

\subsection{Material}

The available data include some CHL-a field measurements with a TriOS MicroFlu device and imagery data of the LANDSAT-8 OLI sensor. The CHL-a measurements were performed at fifteen locations within the lake (Figure 1(b)), during the June 19, 2016 LANDSAT satellite overpass, using a TriOS MicroFlu-Chl-a Fluorometer Sensor that measures the fluorescence emitted by the CHL-a pigment when it is excited by sunlight. When the in-water CHL-a pigment is illuminated, it absorbs some part of the received energy (essentially in the red and blue wavelengths) and re-emits it proportionately (at around $680 \mathrm{~nm}$ wavelength) in amounts that can be quantified by the MicroFLU device using an embedded lens. The TriOS MicroFlu thus measures the energy emission from which the lake CHL-a concentration can be predicted using a decoding computer program.

The imagery database are images taken in the years 2013 and 2016 over the lake by the LANDSAT 8 OLI sensor that encompasses 11 spectral bands whose characteristics are listed in Table 1.

Table 1. Characteristics of the spectral bands of LANDSAT 8 (OLI sensor).

\begin{tabular}{ccc}
\hline Spectral Bands & Wave length & Spatial resolution \\
\hline Band 1-coastal aerosol & $0.433-0.453 \mu \mathrm{m}$ & $30 \mathrm{~m}$ \\
Band 2-Blue & $0.45-0.515 \mu \mathrm{m}$ & $30 \mathrm{~m}$ \\
Band 3-Green & $0.525-0.600 \mu \mathrm{m}$ & $30 \mathrm{~m}$ \\
Band 4-Red & $0.630-0.680 \mu \mathrm{m}$ & $30 \mathrm{~m}$ \\
Band 5-Near infrared & $0.845-0.885 \mu \mathrm{m}$ & $30 \mathrm{~m}$ \\
Band 6-SWIR-1 & $1.560-1.660 \mu \mathrm{m}$ & $30 \mathrm{~m}$ \\
Band 7-SWIR-2 & $2.100-2.300 \mu \mathrm{m}$ & $30 \mathrm{~m}$ \\
Band 8-Panchromatic & $0.500-0.680 \mu \mathrm{m}$ & $15 \mathrm{~m}$ \\
Band 9-Cirrus & $1.360-1.390 \mu \mathrm{m}$ & $30 \mathrm{~m}$ \\
Band 10-Thermal infrared-1 & $10.30-11.30 \mu \mathrm{m}$ & $100 \mathrm{~m}$ \\
Band 11-Thermal infrared-2 & $11.50-12.50 \mu \mathrm{m}$ & $100 \mathrm{~m}$
\end{tabular}




\subsection{Methods}

Researches about extracting water quality parameters (WQPs) of surface waters from satellite imagery have been the subject of several studies ([16]). Numerous case studies have demonstrated the use of reflectance measurements in the visible range (400 - $700 \mathrm{~nm}$ ) for chlorophyll-a (CHL-a) mapping. ([17]) used the ratio of the Green/Red spectral bands to estimate and map the CHL-a contents in the waters of Lake Monticchio in southern Italy. ([18]) demonstrated the efficiency of the Blue/Red bands ratio for mapping the CHL-a in the waters of the Pensacola Bay in Florida. According to the theory, the numerical values of the concentration of WQPs can be derived from the parametric (processed) image by measuring the spectral reflectance in different wave lengths.

\subsubsection{Image Corrections}

The first stage of this study involved data processing of LANDSAT 8 images, which consisted of the following steps (Figure 2):

1) Some geometric corrections up to level-T1 were carried out. The final result was a geometrically corrected product with regards to distortions related to the angle of view of the sensor, the altitude differences of the satellite passes due to the curvature of the Earth globe.

2) Radiometric and atmospheric corrections to eliminate distortions related to illumination conditions, atmospheric effects and other additional noises that pollute the signal recorded by the OLI sensor. These corrections enabled the derivation of the real contribution of the target water surface to the signal, and then measuring its physical values (in terms of radiance and reflectance) in relation to state changes over time. The conversion of radiance to reflectance was made according to the formula of ([19]), while atmospheric corrections used the ATCOR module of ERDAS IMAGINE ([20]).

3) In addition to the above corrections, it was necessary to extract the surface water area of the lake from the studied scenes (Figure 3 ). This was performed by removing unwanted pixels (viz., sand bars or islands and aquatic vegetation populating the lake margins) from the image by using the method of ([21]). An image file matching the shape and the whole lake extension was generated using

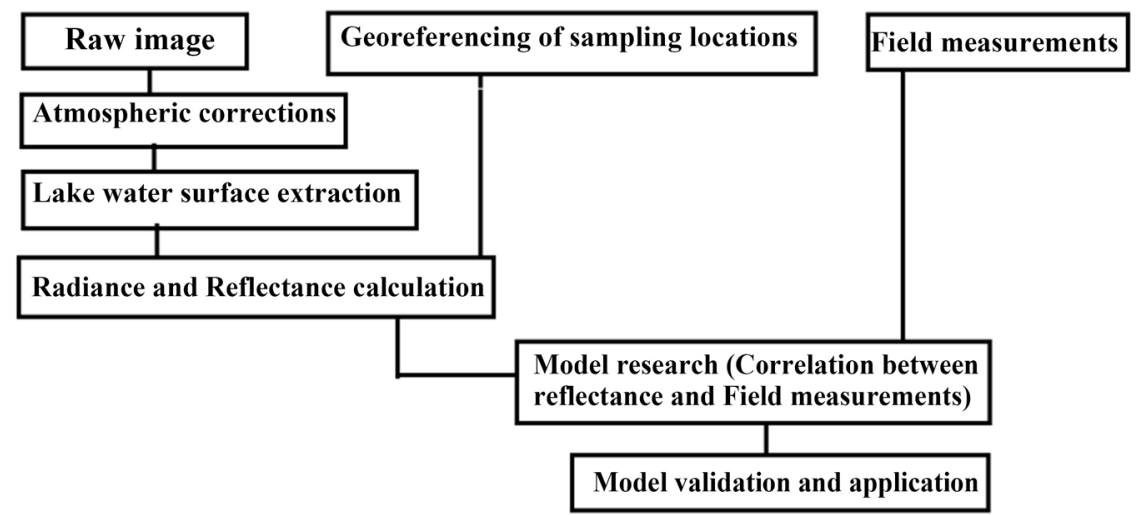

Figure 2. Methodology of the study. 


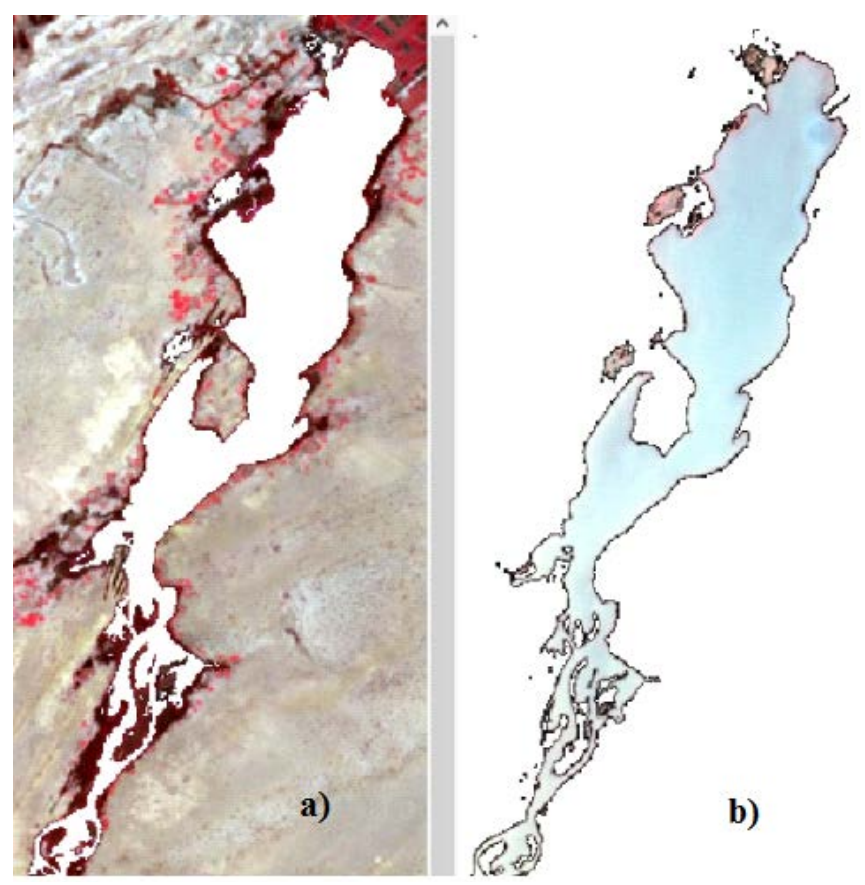

Figure 3. Multi spectral LANDSAT 8 scene of Guiers Lake before extraction (a), and extracted surface water extension of the lake after mask application (b).

the Modified Normalized Difference Water (MNDWI) Index proposed by ([22]) for calculating the water index.

\subsubsection{Spectral Reflectance Calculation Based on In-Situ Point Measurements}

To build up an algorithm that could transform LANDSAT 8 images of Lake Guiers into chlorophyll-a (CHL-a) concentration maps, the position of the measurement points shown in Figure 1(b) were geo-referenced using ERDAS Imagine (version 2014). Then, the signals of the corresponding pixels (its reflectance value) were related to the CHL-a contents measured in those pixel locations at the time of the satellite overpass. This was accomplished by assigning to each measurement point the calculated reflectance value for the pixel. Hence, the spectral profile recorded at the different measurement points made it possible to derive the reflectance in each of the bands of the parametric image.

\subsubsection{Statistical Modelling of CHL-a Content as a Function Reflectance}

After deriving the pixel reflectance of the 15 measuring points on the processed image, a series of correlation tests between the measured CHL-a concentrations and the spectral reflectance of the corresponding pixels (in the visible, infra-red, and near-infrared bands) were run. This is followed by the search for the best regression equation (or prediction model) that could be used to develop our algorithm. Table 2 presents some results of the correlation tests. However, by changing the nature of the law (linear or power law), and/or changing the reference bands (single or multiple correlation), it appeared that the reflectance of the visible bands have a poor correlation. 
Table 2. Summary statistic of the correlation tests between CHL-a point measurements and satellite spectral bands.

\begin{tabular}{cccc}
\hline Independent Variables & Regression Equation & $R^{2}$ Coefficient & P-Values \\
\hline B2 & {$[$ CHL-a $]=-0.211 * \mathrm{~B} 2+10.59$} & 0.000 & 0.993 \\
B3 & {$[$ CHL-a $]=15.55 * \mathrm{~B} 3+9.821$} & 0.035 & 0.501 \\
B4 & {$[$ CHL-a $]=3.368 * \mathrm{~B} 4+10.38$} & 0.001 & 0.887 \\
B5 & {$[$ CHL-a $]=31.56 * \mathrm{~B} 5+9.481$} & 0.106 & 0.2358 \\
$\frac{\mathrm{B} 4}{\mathrm{~B} 3}$ & {$[\mathrm{CHL}-\mathrm{a}]=2.383 *\left(\frac{\mathrm{B} 4}{\mathrm{~B} 3}\right)+13.95$} & 0.441 & 0.00685 \\
$\frac{\mathrm{B} 5}{\mathrm{~B} 4}$ & {$[\mathrm{CHL}-\mathrm{a}]=-3.123 *\left(\frac{\mathrm{B} 2+\mathrm{B} 4}{\mathrm{~B} 3}\right)+16.03$} & 0.522 & 0.00231 \\
$\frac{\mathrm{B} 2+\mathrm{B} 4}{\mathrm{~B} 3}$ & {$[\mathrm{CHL}-\mathrm{a}]=-3.123 *\left(\frac{\mathrm{B} 2}{\mathrm{~B} 4}+\frac{\mathrm{B} 4}{\mathrm{~B} 3}\right)+15.89$} & 0.529 & 0.00209 \\
$\frac{\mathrm{B} 2}{\mathrm{~B} 4}+\frac{\mathrm{B} 4}{\mathrm{~B} 3}$ & {$[\mathrm{~B} 4)+8.231$} & 0.275 & 0.0444 \\
$\frac{\mathrm{B} 3-\mathrm{B} 2}{\mathrm{~B} 4}+\frac{\mathrm{B} 5}{\mathrm{~B} 3}+\mathrm{B} 2+\mathrm{B} 5$ & {$[\mathrm{CHL}-\mathrm{a}]=9.19 *\left(\frac{\mathrm{B} 3-\mathrm{B} 2}{\mathrm{~B} 4}+\frac{\mathrm{B} 5}{\mathrm{~B} 3}+\mathrm{B} 2+\mathrm{B} 5\right)+2.814$} & 0.693 & 0.000117 \\
$\frac{\mathrm{B} 3-\mathrm{B} 2+\mathrm{B} 5}{\mathrm{~B} 4}$ & {$[\mathrm{CHL}-\mathrm{a}]=3.4 *\left(\frac{\mathrm{B} 3-\mathrm{B} 2+\mathrm{B} 5}{\mathrm{~B} 4}\right)+2.37$} & 0.703 & $9.395 .10^{-5}$ \\
$\frac{\mathrm{B} 3-\mathrm{B} 2+\mathrm{B} 5}{\mathrm{~B} 4}+\mathrm{B} 4$ & {$[\mathrm{CHL}-\mathrm{a}]=6.43 *\left(\frac{\mathrm{B} 3-\mathrm{B} 2+\mathrm{B} 5}{\mathrm{~B} 4}+\mathrm{B} 4\right)+3.697$} & 0.639 & 0.000348 \\
\hline
\end{tabular}

The regression equation that provided the best prediction model of CHL-a (dependent variable $Y$ ), was obtained by correlating the reflectance ratios of the visible and near-infrared bands (independent variables), as follows (see Figure 4):

$$
Y=3.4 *\left(\frac{(\mathrm{B} 3-\mathrm{B} 2)}{\mathrm{B} 4}+\frac{\mathrm{B} 5}{\mathrm{~B} 4}\right)+2.37
$$

where B2 is Blue band; B3 is Green band; B4 is Red band and B5is NIR band. The coefficient of determination $R^{2}$ is 0.703 (i.e., a correlation coefficient $r=\sqrt{\left(R^{2}\right)}$ of 0.84$)$, and the P-value of $9,39514 \cdot 10^{-5}$ suggest that the measured concentrations are well reproduced by the model.

\subsubsection{Evaluation of the Prediction Model}

To illustrate the goodness of fit of the Equation (1), the predicted values were compared to the observed ones in Figure 5 with a good match between values as revealed by the coefficient of determination $R^{2}$ is 0.8954 (i.e., a correlation coefficient $r$ of 0.946). The average Root Mean Square Error (RMSE) was 0.825 , which suggests a fair reproducibility of the observation data, and reliability of Equation (1) for transforming LANDSAT 8 images into CHL-a concentration maps. Hence, it was appropriate to apply this model to image data of the years 2013 and 2016 for a comparative assessment as discussed in the below. First of all, the discussion presents the monthly variations of the CHL-a concentrations during the observation years, then followed by seasonal variations (or evolution) and interannual trend as well as conclusion. 


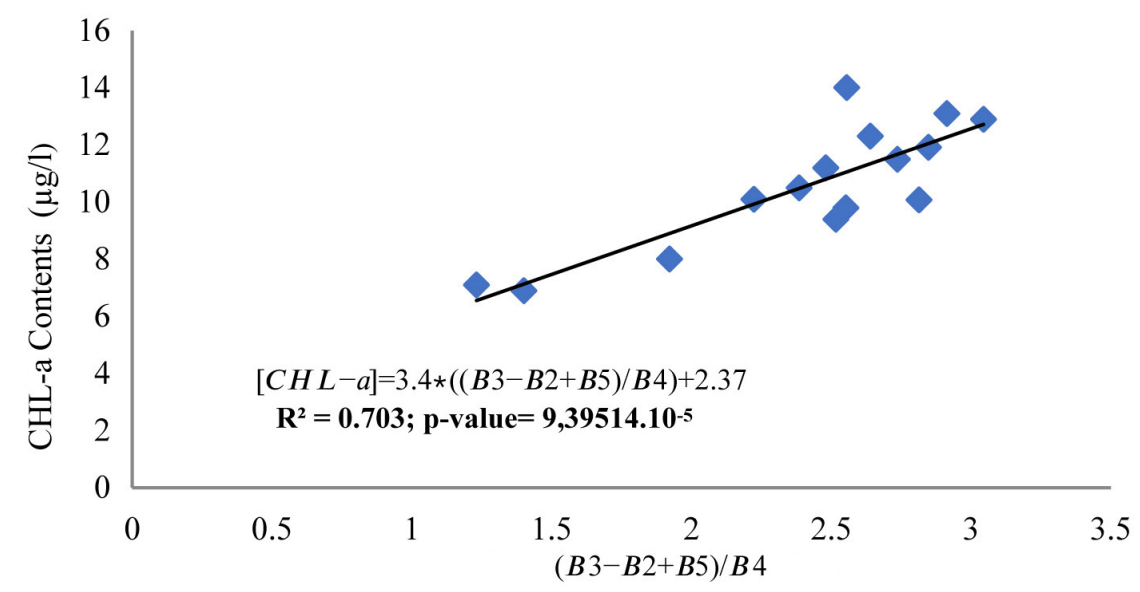

Figure 4. The best fitting equation between in-situ measurements and spectral band ratios B2, B3, B4 and B5.

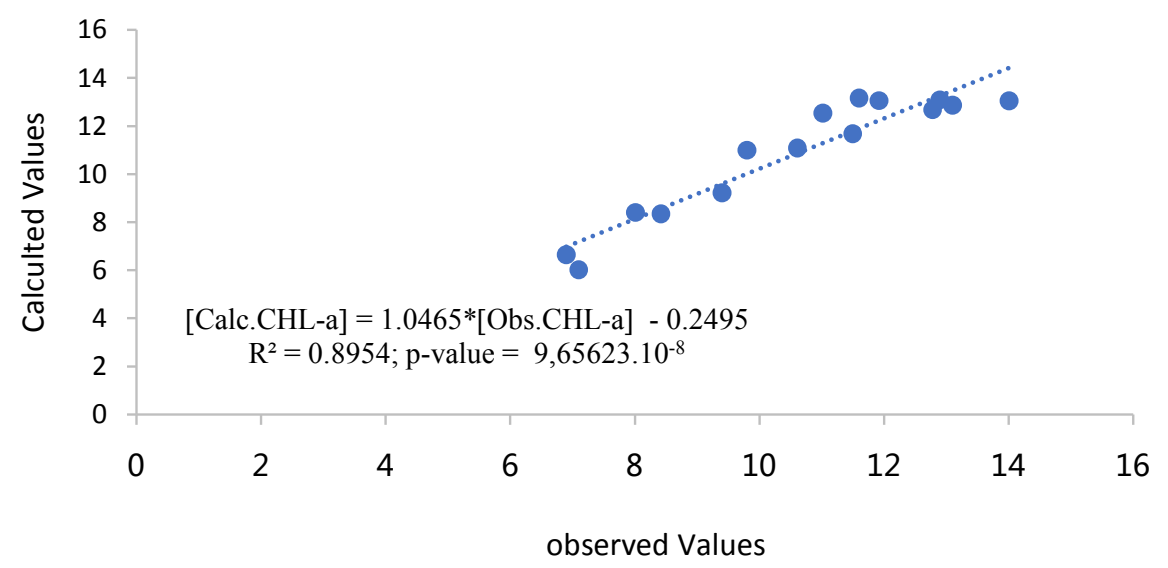

Figure 5. Correlation between calculated and observed CHL-a values.

\section{Results and Discussions}

Results from the correlation tests revealed a very poor relationship between the in-situ measurements and the spectral reflectance of the individual visible bands (i.e. bands B2, B3, B4 and B5) with a very low coefficient of determination $\left(R^{2} \leq\right.$ 0.106 ; see Table 2). The implication is that using the visible spectral bands separately was not a good approach in search of a good prediction model. However, a clear improvement was noticed there by combining the spectral band ratios as an independent variable and made it possible to obtain a significant degree of correlation $\left(R^{2} \geq 0.5\right.$; p-value $\left.<0.00231\right)$. Apparently, the degree of correlation increased significantly when several band ratios (multi-variable regression) were combined as terms of the independent variables. Hence, the obtained coefficient $R^{2}$ of more than 0.5 is an indication of better (significant) correlation.

\subsection{Monthly Variations}

As shown in the maps of Figure 6, the range of the variations of the monthly mean CHL-a concentrations did not contrast significantly over the considered period. The values range between a minimum of $4.3 \mu \mathrm{g} / \mathrm{L}$ and a maximum of 

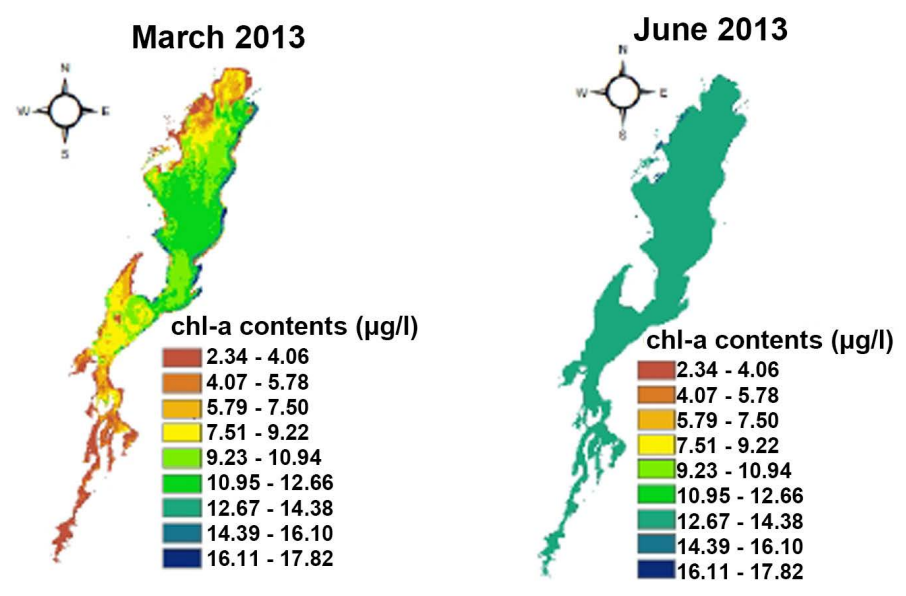

May 2016

January 2016
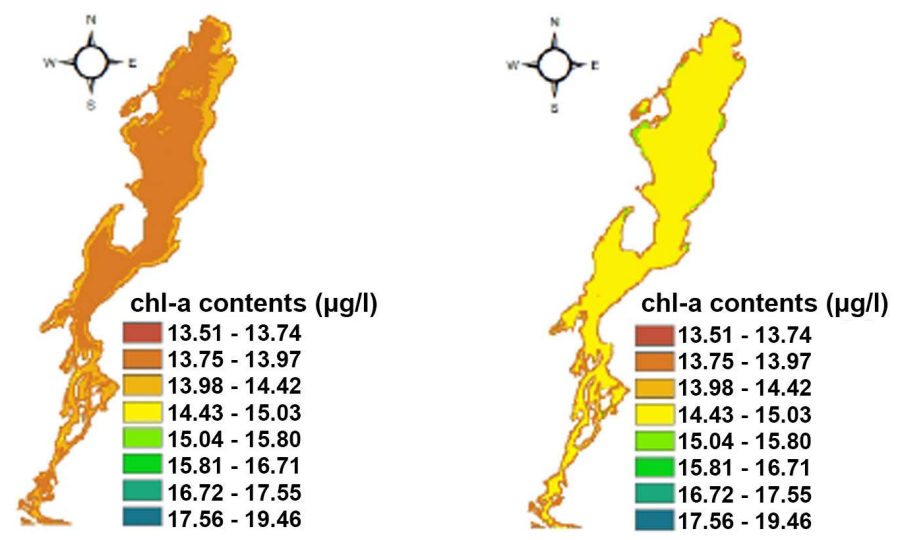

Figure 6. Maps of lowest and highest monthly mean CHL-a concentrations in 2013 and 2016. [Note that the small contrast in the CHL-a values recorded in $2016(13.51 \mu \mathrm{g} / \mathrm{L} \leq$ CHL-a $\leq 19.81 \mu \mathrm{g} / \mathrm{L})$, as compared to those of $2013(4.03 \mu \mathrm{g} / \mathrm{L} \leq \mathrm{CHL}-\mathrm{a} \leq 19.81 \mu \mathrm{g} / \mathrm{L}) \mathrm{did}$ not allow us to adopt the same legend for the illustration maps of these two years.].

$19.81 \mu \mathrm{g} / \mathrm{L}$ during this period. These values are in the same range of those found by ([23]), but are slightly lower than those reported by ([24]) and ([25]).

In 2013, the lowest CHL-a concentration $(4.03 \mu \mathrm{g} / \mathrm{L})$ was observed in March and the highest $(19.73 \mu \mathrm{g} / \mathrm{L})$ was detected in June. In 2016, the lowest value $(13.03 \mu \mathrm{g} / \mathrm{L})$ was recorded in January and the highest in May $(19.81 \mu \mathrm{g} / \mathrm{L})$. CHL-a $\geq 8 \mu \mathrm{g} / \mathrm{L}$ were by far the majority in the recorded values. The range of variation and order of magnitude of the recorded values suggested a changing trophic level of the lake waters, from "Oligo-Mesotrophic" ( $1 \mu \mathrm{g} / \mathrm{L} \leq \mathrm{CHL}-\mathrm{a} \leq 8$ $\mu \mathrm{g} / \mathrm{L})$ to "Mesotrophic-Eutrophic" (8 $\mu \mathrm{g} / \mathrm{L} \leq \mathrm{CHL}-\mathrm{a} \leq 25 \mu \mathrm{g} / \mathrm{L})$ (Table 3; [26]); representing a "nutrient-poor" to "moderately nutrient-rich" lake environment.

\subsection{Seasonal Variations}

The seasonal variations of the CHL-a concentrations during the course of 2013 and 2016 were also addressed. The seasonal concentration maps were established based on the average monthly mean concentration maps. Table 4 summarizes 
Table 3. Criteria for assessing the trophic level of a lake (modified after [26]).

\begin{tabular}{ccccc}
\hline Trophic level & Nutrients enrichment & $\begin{array}{c}\text { Total Phosphorus } \\
(\mu \mathrm{g} / \mathrm{l})\end{array}$ & $\begin{array}{c}\mathrm{CHL}-\mathrm{a}(\mu \mathrm{g} / \mathrm{l}) \\
\begin{array}{c}\text { Water transparency } \\
(\mathrm{m})\end{array}\end{array}$ \\
\hline Oligotrophic & Low nourrished waters & $\leq 10$ & $\leq 3$ & $\geq 5$ \\
Oligo-mesotrophic & Moderately nourrished & $7-13$ & $2.5-3.5$ & $4-6$ \\
Mesotrophic & waters & $10-30$ & $3-8$ & $2.5-5$ \\
Meso-eutrophic & Well nourrished waters & $20-35$ & $6.5-10$ & $2-3$ \\
Eutrophic & & $>30$ & $>8$ & $<2.5$ \\
\hline
\end{tabular}

Table 4. Range of the seasonal variation of CHL-a concentrations.

\begin{tabular}{ccccc}
\hline \multirow{2}{*}{ Period } & \multicolumn{2}{c}{ Year 2013 } & \multicolumn{2}{c}{ Year 2016 } \\
\cline { 2 - 5 } & Minimum & Maximum & Minimum & Maximum \\
\hline Cold season & $4.03 \mu \mathrm{g} / 1$ & $16.24 \mu \mathrm{g} / \mathrm{l}$ & $13.03 \mu \mathrm{g} / 1$ & $17.05 \mu \mathrm{g} / \mathrm{l}$ \\
Summer season & $12.10 \mu \mathrm{g} / \mathrm{l}$ & $19.73 \mu \mathrm{g} / \mathrm{l}$ & $13.20 \mu \mathrm{g} / \mathrm{l}$ & $19.81 \mu \mathrm{g} / \mathrm{l}$ \\
Rainy season & $7.008 \mu \mathrm{g} / 1$ & $18.02 \mu \mathrm{g} / \mathrm{l}$ & $13.05 \mu \mathrm{g} / 1$ & $17.63 \mu \mathrm{g} / \mathrm{l}$ \\
\hline
\end{tabular}

the results of mean seasonal concentration maps for a cold period/winter season (from January to March), a summer/hot season (from April to June), and a rainy season (from July to October).

Seasonal variations in 2013: Figure 7 shows the variation of the mean seasonal CHL-a concentration of the lake waters during 2013; while Table 5 displays the statistical distribution of concentrations in terms of per cent of the lake areal extend based on 5 classes of the CHL-a concentrations.

As shown in Figure 7 the CHL-a contents of the lake vary seasonally in the course of the year while the CHL-a values are lower during the cold season during which nearly $38 \%$ of the lake surface has a eutrophic level (CHL-a $\geq 8 \mu \mathrm{g} / \mathrm{L}$ ). However, the concentrations increased, to reach their maximum during summer (hot season), corresponding to the period when the water surface is warmer, thus building euphotic conditions that favour an algal bloom. During this period, nearly $92 \%$ of the lake area has a eutrophic level (see Table 5). The CHL-a concentrations followed afterward a declining trend during the rainy season, a period during which, however, nearly $75 \%$ of the lake waters still exhibit a eutrophic level.

Seasonal variations in 2016: In 2016, a seasonal trend that was quite similar to the one reported for 2013 was observed (Figure 8), however, with higher numerical values. Table 6 revealed that all CHL-a values exceed the safety margin of 9 - $10 \mathrm{CHL}-\mathrm{a} \mu \mathrm{g} / \mathrm{L}$ applied to lake waters by the Bureau of Water ([27]). These are limit-values beyond which some taste and smell problems might arise, which imply unsuitability as drink water.

The CHL-a concentrations records in 2016 place the entire lake system on the eutrophic level. This indicates a profound change in the ecosystem between 2013 and 2016. It should be noted that the consequence of eutrophication of surface 
Table 5. Statistics of the mean seasonal CHL-a concentration in terms percentage of the lake areal extend, after classification into 5 classes (2013).

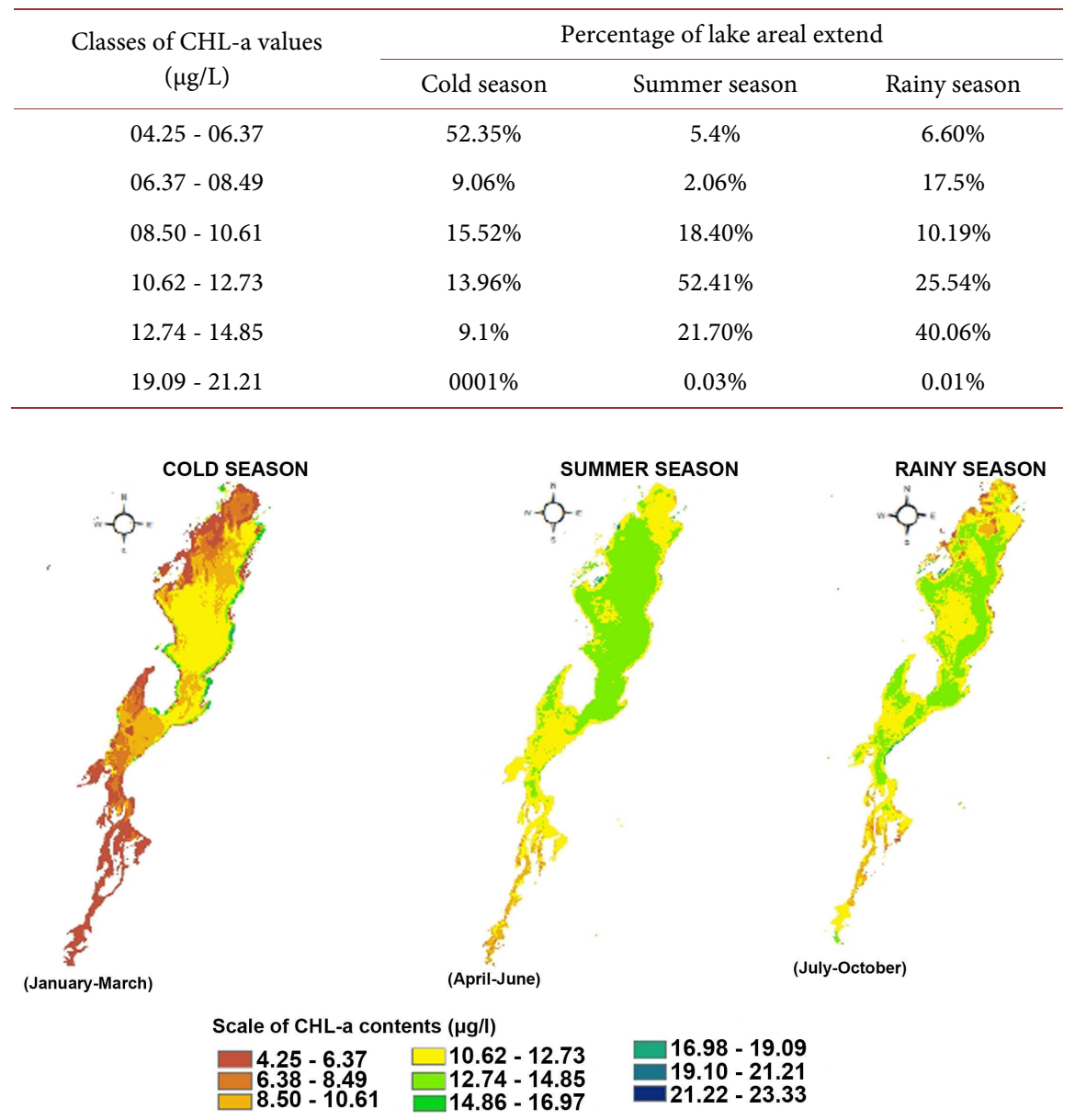

Figure 7. Mean seasonal CHL-a concentration maps for 2013.

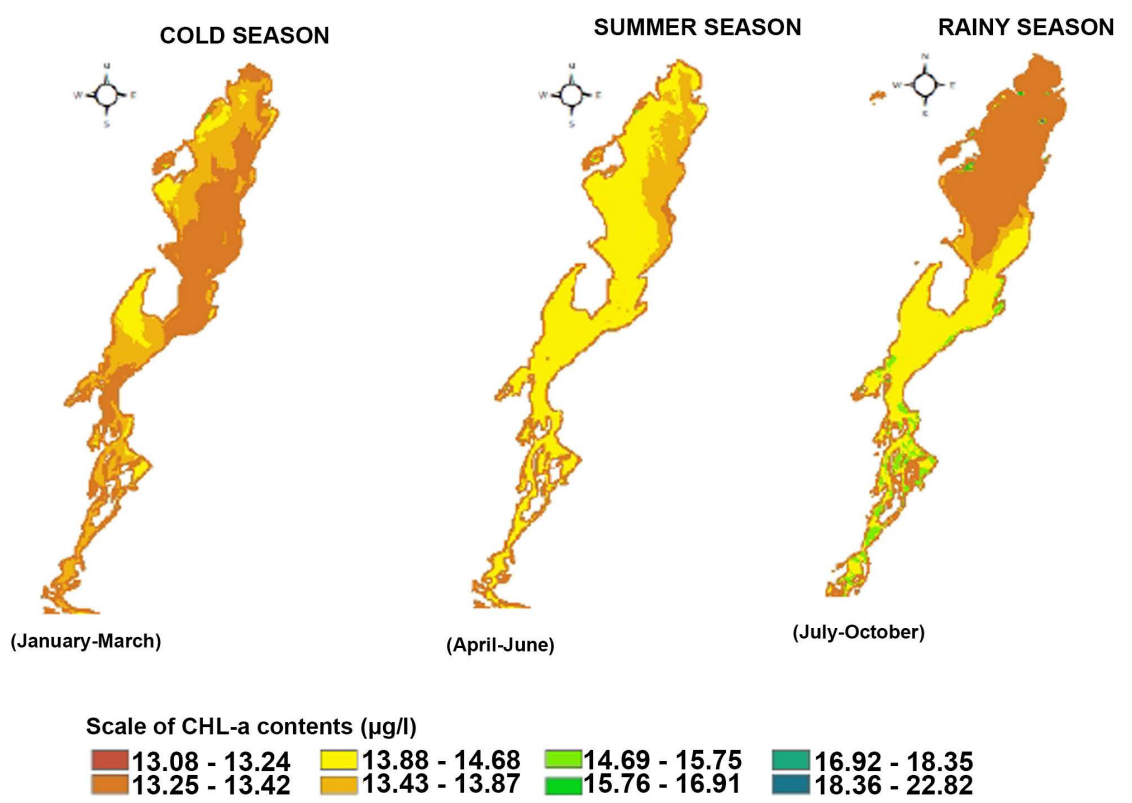

Figure 8. Mean seasonal CHL-a concentration maps for 2016. 
Table 6. Statistics of the mean seasonal CHL-a concentration in terms percentage of the lake areal extend, after classification into 5 classes (2016).

\begin{tabular}{cccc}
\hline \multirow{2}{*}{ Classes of CHL-a values $(\mu \mathrm{g} / \mathrm{L})$} & \multicolumn{3}{c}{ Percentage of Lake areal extend } \\
\cline { 2 - 4 } & Cold season & Summer season & Rainy season \\
\hline $13.08-13.24$ & $43.04 \%$ & $0.80 \%$ & $44.75 \%$ \\
$13.25-13.42$ & $41.00 \%$ & $18.51 \%$ & $5.24 \%$ \\
$13.43-13.87$ & $14.74 \%$ & $79.00 \%$ & $38.50 \%$ \\
$13.88-14.68$ & - & - & $9.53 \%$ \\
\hline
\end{tabular}

waters is the proliferation of aquatic plants, and also algae that could produce toxins, tastes and odours. Moreover, the development of algae increases the consumption of dissolved oxygen in surface waters and might lead to a replacement of the existing organisms by new species that better adapt to the new conditions.

\section{Summary and Conclusions}

In general, the southern (downstream) part of the lake is characterized by the lower CHL-a values $(4.5 \mu \mathrm{g} / \mathrm{L} \leq \mathrm{CHL}-\mathrm{a} \leq 12.75 \mu \mathrm{g} / \mathrm{L})$, regardless of the season. This suggests that the conditions for an algal development are not so favourable in this part of the lake. On the overall, the lake CHL-a concentration is higher in summer, during the hot season from April to June, while the highest values $(\mathrm{CHL}-\mathrm{a} \geq 15-16 \mu \mathrm{g} / \mathrm{L})$ generally occur in the central parts and in the inhabited banks of the lake. These high values can be related to the impact of anthropogenic contamination on the lake environment through nutrients enrichment of nitrogen and phosphorous which is the direct cause of eutrophication trough algal bloom. The origin of this nutrient enrichment (fertilization) of the lake waters may be twofold:

1) The use of fertilizers within the agricultural perimeters bordering the lake, the leaching of which can enrich the lake waters with nutrients; and

2) The domestic activities of riverine populations (household activities, wastewaters disposal, laundry and fishing) that may drain nutrients into the lake.

This study had demonstrated the applicability of LANDSAT-8 imageries in the assessment of CHL-a content of Lake Guiers water. It also demonstrates effectiveness of the technique employed as a rapid assessment tool to monitor this important water quality parameter. The diachronic study of LANDSAT 8 image records of the lake in the years 2013 and 2016 revealed monthly variations of the lake CHL-a contents, as well as the seasonal evolution and interannual variations. The findings are quite consistent with those from previous works and provided valuable information regarding the trophic status of the Lake Guiers and its vulnerability to algal development. The findings point out to a general tendency of eutrophication process, leading to a progressive degradation of the quality of the water resource in the study area. 


\section{Conflicts of Interest}

The authors declare no conflicts of interest regarding the publication of this paper.

\section{References}

[1] I.S.E. (1983) Lake Guiers: Environmental and Development Issues. Proceedings of I.S.E. Symposium, 9-11 May 1983, 506 p.

[2] Niang, A. (1999) Environmental Monitoring and Water Quality Management of Lake Guiers. PhD Thesis in Physical Geography, FLSH, Department of Geography, UCAD, Dakar, 348 p.

[3] Spitzer, D. and Dirks, R.W.J. (1985) Contamination of the Reflectance of Natural Waters by Solar-Induced Fluorescence of Dissolved Organic Matter. Applied Optics, 24, 444-445. https://doi.org/10.1364/AO.24.000444

[4] Baban Serwan, M.J. (1993) Detecting Water Quality Parameters in Norfolk Broads, U.K., Using Landsat Imagery. International Journal of Remote Sensing, 14, 12471267. https://doi.org/10.1080/01431169308953955

[5] Miller, R.L., Mckee, B.A. and D’sa, E. (2005) Monitoring Bottom Sediment Resuspension and Suspended Sediments in Shallow Coastal Waters. In: Miller, R.L., Del Castillo, C.E. and McKee, B.A., Eds., Remote Sensing of Coastal Aquatic Environments, Springer, Berlin, 259-276. https://doi.org/10.1007/1-4020-3100-9_11

[6] Gitelson, A., Mayo, M., Yacobi, Y.Z. and Ben-Avraham, Z. (1995) Chlorophyll Distribution in Lake Kinneret Determined from Landsat Thematic Mapper Data. International Journal of Remote Sensing, 16, 175-182.

https://doi.org/10.1080/01431169508954386

[7] Dekker, A.G., Voss, R.J. and Peters, S.W.M. (2002) Analytical Algorithms for Lake Water TSM Estimation for Retrospective Analysis of TM and SPOT Sensor Data. International Journal of Remote Sensing, 23, 15-35. https://doi.org/10.1080/01431160010006917

[8] Lathrop, R.G. (1992) Landsat Thematic Mapper Monitoring of Turbid Inland Water Quality. Photogrammetric Engineering and Remote Sensing, 58, 465-470.

[9] Olmanson, L.G., Brezonik, P.L., Finlay, J.C. and Bauer, M.E. (2016) Comparison of Landsat 8 and Landsat 7 for Regional Measurements of CDOM and Water Clarity in Lakes. Remote Sensing of Environment, 185, 119-128. https://doi.org/10.1016/j.rse.2016.01.007

[10] Bilgehan, N., Karabork, H., Ekercin, S. and Berktay, A. (2009) Mapping Chlorophyll-a Through In-Situ Measurements and Terra ASTER Satellite Data. Environmental Monitoring and Assessment, 157, 375-382. https://doi.org/10.1007/s10661-008-0542-9

[11] Brivio, P.A., Giardino, C. and Zilioli, E. (2001) Determination of Chlorophyll Concentration Changes in Lake Garda Using an Image-Based Radiative Transfer Code for Landsat TM Images. International Journal of Remote Sensing, 22, 487-502. https://doi.org/10.1080/014311601450059

[12] Mbaye, A.D. (2013) Environmental and Social Management Project Scheme for Resoring the Lake Guiers Socio-Ecological Functions. PREFELAG, Final Report, 48 p.

[13] Cogels, F.X., Carn, M., Niang, A. and Gac, J.Y. (1993) The Quality of Lake Guiers Waters 1. Qualitative Assessment 2. Colleteral Effects of Development Activities in the Senegal River 3. Primary Use of a Model for Qualitative Management. Doc. 
Multigr, ORSTOM EEC, $52 \mathrm{p}$.

[14] Cogels, F.X. (1994) The Quality of Surface Waters in the Senegal River Delta and in Lake Guiers. ORSTOM Documentary Fund, $48 \mathrm{p}$.

[15] Gac, J.Y., Cogels, F.X., Niang, A. and Coly, A. (1994) General Study of the Lacustrine System and of Its Management Problem. Doc ORDTOM, 69 p.

[16] Brezonik, P., Kevin, D., Menken and Bauer, M. (2005) Landsat-Based Remote Sensing of Lake Water Quality Characteristics, Including Chlorophyll and Colored Dissolved Organic Matter (CDOM). Lake and Reservoir Management, 21, 373-382. https://doi.org/10.1080/07438140509354442

[17] Mancino, G., Nolè, A., Urbano, V., Amato, M. and Ferrara, A. (2009) Assessing Water Quality by Remote Sensing in Small Lakes: The Case Study of Monticchio Lakes in Southern Italy. iForest, 2, 154-161. https://doi.org/10.3832/ifor0507-002

[18] Han, L. and Jordan, K.J. (2005) Estimating and Mapping Chlorophyll-a Concentration in Pensacola Bay, Florida Using Landsat ETM+ Data. International Journal of Remote Sensing, 26, 5245-5254. https://doi.org/10.1080/01431160500219182

[19] Chander, G., Markham, B.L. and Helder, D.L. (2009) Summary of Current Radiometric Calibration Coefficients for Landsat MSS, TM, ETM+, and EO-1 ALI Sensors. Remote Sensing of Environment, 113, 893-903.

https://doi.org/10.1016/j.rse.2009.01.007

[20] ERDAS IMAGINE (HexagonGeospatial, Version 2014). https://www.hexagongeospatial.com/resources/support

[21] Olmanson, L.G., Kloiber, S.M., Bauer, M.E. and Brezonik, P.L. (2001) Image Processing Protocol for Regional Assessments of Lake Water Quality. Water Resources Center and Remote Sensing Laboratory, Univ. of Minnesota, St. Paul.

[22] Wu, C., Wu, J., Qi, J., Zhang, L., Huang, H., Lou, L. and Chen, Y. (2010) Empirical Estimation of Total Phosphorus Concentrations in the Mainstream of the Quintang River in China Using Landsat TM Data. International Journal of Remote Sensing, 31, 2309-2324. https://doi.org/10.1080/01431160902973873

[23] DHI/Tropis (2005) Development of the Management Scheme for Lake Guiers, PLT (Long-Term Water Project). Final Diagnostic Report, 222 p.

[24] Ba, N. (2006) The Phytoplankton Community of Lake Guiers (Senegal): Types of Functional Associations and Experimental Approaches of the Regulating Factors. Doctoral Thesis in Ecology, Department of Biology, FST, UCAD, Dakar, 159 p.

[25] Diop, S., Wade, S. and Tijani, M.N. (2016) Feasibility Analysis of MERIS as a Tool for Monitoring Lake Guiers (Senegal) Water Quality. Journal of Water Resource and Protection, 8, 100-119. https://doi.org/10.4236/jwarp.2016.81009

[26] RAPPEL (Regroupement des Associations Pour la Protection de l'Environnement des Lacs et des cours d'eau de l'Estrie et du haut bassin de la rivière Saint-François) (2009) Suivi de l'eau-été 2009. Lac Long Pond; Réd. M. Dubois, Sherbrooke, 14 p. [RAPEL-Regrouping Associations for the Protection of the Environment of the Lakes and Waterways of Estrie and the Upper Saint-François River Basin: Water Monitoring, Summer 2009, Lake Long Pond; Redaction by M. Dubois, Sherbrooke, $14 \mathrm{p}]$.

http://laclongpond.org/sites/laclongpond.org/files/Ete\%202009_Suivi\%20Eau_Long _Pond_1.pdf

[27] Kansas Department of Health and Environment, Bureau of Water (2011). http://www.kdheks.gov/water/download/tech/Duration_Frequency_final_Jan27.pdf 